\title{
"Flexibility of creating and changing employment in the options of the Slovak Labor Code"
}

\begin{tabular}{|c|c|}
\hline AUTHORS & Tomáš Peráček (iD) \\
\hline ARTICLE INFO & $\begin{array}{l}\text { Tomáš Peráček (2021). Flexibility of creating and changing employment in the } \\
\text { options of the Slovak Labor Code. Problems and Perspectives in Management, } \\
\text { 19(3), 373-382. doi:10.21511/ppm.19(3).2021.30 }\end{array}$ \\
\hline DOI & http://dx.doi.org/10.21511/ppm.19(3).2021.30 \\
\hline RELEASED ON & Monday, 20 September 2021 \\
\hline RECEIVED ON & Wednesday, 21 July 2021 \\
\hline \multirow[t]{2}{*}{ ACCEPTED ON } & Thursday, 09 September 2021 \\
\hline & $(\mathrm{cc}) \mathrm{EY}$ \\
\hline LICENSE & $\begin{array}{l}\text { This work is licensed under a Creative Commons Attribution } 4.0 \text { International } \\
\text { License }\end{array}$ \\
\hline JOURNAL & "Problems and Perspectives in Management" \\
\hline ISSN PRINT & $1727-7051$ \\
\hline ISSN ONLINE & $1810-5467$ \\
\hline PUBLISHER & LLC "Consulting Publishing Company "Business Perspectives" \\
\hline FOUNDER & LLC "Consulting Publishing Company "Business Perspectives" \\
\hline & E:- \\
\hline NUMBER OF REFERENCES & NUMBER OF FIGURES \\
\hline 28 & 0 \\
\hline
\end{tabular}

(C) The author(s) 2021. This publication is an open access article. 


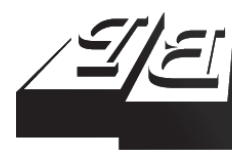

\section{BUSINESS PERSPECTIVES}

LLC "CPC "Business Perspectives" Hryhorii Skovoroda lane, 10, Sumy, 40022, Ukraine www.businessperspectives.org
Received on: $21^{\text {st }}$ of July, 2021 Accepted on: $9^{\text {th }}$ of September, 2021 Published on: $20^{\text {th }}$ of September, 2021

๑ Tomáš Peráček, 2021

Tomáš Peráček, Ph.D., Professor, Faculty of Management, Department of Information Systems, Comenius University in Bratislava, Slovak Republic.
Tomáš Peráček (Slovak Republic)

\section{FLEXIBILITY OF CREATING AND CHANGING EMPLOYMENT IN THE OPTIONS OF THE SLOVAK LABOR CODE}

\begin{abstract}
Flexibility of the employer's ability to manage human resources during the severalmonth "lockdown" due to the COVD-19 pandemic has proven crucial to the survival of a Slovak company. However, this flexibility, unlike other contractual relationships, is strictly regulated by the Slovak Labor Code. Given the scope of the problem, the paper focuses only on issues related to the possibility of creating and changing employment in the Slovak Republic, which must be addressed by the management of all companies. The main purpose of the study is to assess flexibility in creating and changing employment. In processing this managerial issue, analysis, synthesis, deduction, and comparison are used. It was found that the Slovak Labor Code is flexible enough and fulfills its purpose. Despite its flexibility, it also provides an employee with the necessary protection in employment relations and allows him, in agreement with an employer, to grant more rights than he himself guarantees. However, in the current information age, it does not allow for electronic conclusions of legal acts and still prefers the paper form. Another disadvantage is the finding that it does not regulate the institute of a management contract, which objectively causes problems between the employer and the manager, especially in the issue of stability of a managerial position.
\end{abstract}

\section{Keywords}

employee, employer, flexibility, Labor Code, management

JEL Classification K31, M12

\section{INTRODUCTION}

The world lives in the era of the fourth industrial revolution. This beginning of the 21st century is fundamentally changing not only our way of life and communication, but also the way we work. The impact of the fourth industrial revolution on the labor market, particularly in the field of human resources management, is unquestionable. The flexibility of human capital is coming to the fore and becoming a key factor for success. Not only when starting a business, but especially during its course and development, employees are one of the decisive factors for success. The prosperity and growth of entrepreneurs depend on their performance, skills and reliability. However, the COVID-19 pandemic unexpectedly exposed a number of unresolved human resource management problems. Not only the quality of employees, but above all the flexibility in the employer's ability to deal with human resources within months of lockdown have proven crucial to the company's survival in this time of crisis. However, this process is subject to strict legal regulation. This means that the management of a company in the Slovak Republic has to comply with current effective legislation when determining its requirements for future employees, which is quite often a problem arising mainly from the ignorance of management. From a legal point of view, it is the issue of establishing and changing the employment relationship, which is primarily regulated 
by the Act of the National Council of the Slovak Republic No. 311/2001 Coll. The amended Labor Code (hereinafter referred to as "Labor Code") sought and currently at least seems to try to respond flexibly to the current needs of the labor market.

\section{LITERATURE REVIEW}

The fundamental concept of labor law is 'employment', by which Prokopenko and Omelyanenko (2018) mean the basic employment relationship arising between an employee and an employer as two equivalent subjects of labor law. This is a bilateral commitment relationship. There, the employee undertakes to perform work for the employer for a pre-agreed wage. The object of employment is the personal performance of the employee. It is determined in kind, not individually. From that, according to Plavčan and Funta (2020), it follows that an employment activity is considered an object of employment, not just its result. The employee's obligation is to continuously perform work of a certain kind within the employment process with the employer.

However, Srebalová and Vojtech (2021) understand the content of the employment relationship as the totality of rights and obligations of both the employer and the employee. According to these authors, an employer is generally obliged to allocate work to an employee according to the employment contract, pay for their performance, create conditions for the performance of the work tasks and comply with other legislation. The employee, according to the employer's instructions, personally carries out the work in a specified place and time and observes the professional discipline. However, the obligations of both the employer and the employee result from mutual agreement, fully respecting the provisions of $\$ 47$ et seq. of the Labor Code.

As Jankurová et al. (2017) warn, before concluding an employment contract, the employer must inform the future employee not only about his rights and obligations arising from his employment contract, but also about his working and pay conditions under which he will perform work. If specific legislation requires medical fitness, mental fitness or other presumption to perform the agreed work, the employer may conclude an employment contract only with a natural person meeting the specified requirements. A special situation arises in the case of the employment of a young worker, i.e. a person under the age of 18 . Kováčik and Imrovič (2019) believe that there have been significant changes compared to the repealed 1965 Labor Code. An employer may conclude an employment contract with a youth only after his or her previous medical examination and after asking for a statement, but no longer the consent of his legal representative, who is usually the parent.

The right of the employer to request information from the employee regarding his civil status is limited by mandatory provision of $\$ 41$ paragraph 5 of the Labor Code. It allows him to request only information relating to the work to be carried out from the applicant for the first job. However, a natural person who has already been employed on several occasions has the right to also request the presentation of a work report and an employment certificate.

As Mucha (2019) recalls, in the context of pre-contractual relations, the employer is strictly prohibited from requesting information from a natural person concerning:

- pregnancy;

- family circumstances;

- a clear criminal extract, unless it is required by a specific regulation or when the requirement of good reputation requires the nature of the work to be carried out by a natural person;

- political affiliation, trade union affiliation and religious affiliation.

In this regard, however, Mura et al. (2019) also refer to the obligation for the future employee to inform the future employer, in particular, not only about the facts hindering the job, but also those that may harm the employer in the future. In practice, for example, if there is a ban on driving applied. A young employee whose total maximum 
length of working time is limited by the Labor Code, in contrast to adult employees, must inform the employer about other employment relationships with other employers.

When recruiting a natural person, a employer must not infringe the principle of equal treatment. This principle applies specifically to the question of access to employment. According to Cajkova et al. (2021), the reason is generally enforced necessity in employment relations to treat employees in accordance with the principle of equal treatment in accordance with Act No. 365/2004 Coll. on equal treatment in certain areas and on protection against discrimination and on amendments to certain laws (anti-discrimination act), as amended. According to Vaníčková and Bílek (2021), "it is prohibited to discriminate against employees on grounds of sex, marital status and family status, sexual orientation, race, colour, language, age, unfavourable state of health or disability, genetic features, belief, religion, political or any other opinion, trade union activity, national or social origin, nationality or ethnic group, property, gender or other status." As further emphasized by Bartekova and Šlahor (2018), violation of these obligations by the employer is sanctioned by the right of a natural person to adequate financial compensation, which the court determines based on his reasoning.

With reference to the literature review and the general lack of interest in managing this issue, the main goal was set, which is to review the current flexibility of creating and changing employment in the context of the options provided by the Labor Code. In addition to the main objective, four milestones have been established:

- verify the possibility of carrying out employment acts electronically;

- verify the existence of a management contract as a separate type of an employment contract;

- identify the biggest legal difficulties that the management of the company must deal with; and

- assess the regulation of the subject under examination and, where appropriate, provide proposals for a "de lege ferenda".
The set goals can be achieved mainly by a thorough study of legislation, professional and scientific literature. Due to the nature of the scientific article, several scientific methods of knowledge are used, suitable for the analysis of management and law as scientific disciplines. This concerns, in particular, the use of critical analysis to review the legal and regulatory situation, as well as abstractions. By applying a comparative method, available different opinions of economists, managers, and especially lawyers are make, not only on the appropriateness of regulation, but also on the interpretation of individual legal institutes.

\section{RESULTS}

\subsection{Establishment of an employment relationship}

The employment relationship is established by a written employment contract between an employer and an employee, the employer being obliged to issue one written copy to the employee, unless the Labor Code stipulates otherwise. However, one very important point should be pointed out here. Despite the current digital era, the Labor Code does not allow the conclusion of an employment contract electronically. Failure to comply with the written form of an employment contract is a very serious violation of the mandatory provisions of the Labor Code; however, it does not mean that the employment relationship is not due to the invalidity of an employment contract. According to Klimek and Funta (2021), the reason is the fact that, in the case of labor law, the legislature penalizes the failure to comply with the formal aspect of a legal transaction. Failure to comply with the written form of legal transaction is affected by a defect of absolute invalidity only if it is expressly provided by the Labor Code, as is the case of termination. However, as further Dudic et al. (2020) add, it would be undeclared work according to the provisions of section 2, paragraph 1 letter a) of Act No. 82/2005 Coll. on Undeclared Work and Undeclared Employment and on Amendments to Certain Acts as amended.

There are cases where a specific rule provides for the choice or appointment as a precondition for performing the function of a statutory body. 
Another option is if the employer's internal regulation provides for the choice or appointment as a requirement to perform the function of a senior employee under the direct managerial competence of a statutory body. In this case, the employment relationship with the staff member shall be established by a written employment contract, but only after his election or appointment.

Mura et al. (2020), however, focus on the mandatory provision of $\$ 43$ paragraph 1 of the Labor Code specifying mandatory (essential) requirements that an employer is obliged to agree with an employee in the employment contract. These are:

a) the type of work for which the staff member is recruited and its brief characteristics;

b) place of employment, that is, part of a municipality or otherwise designated place;

c) day of starting work;

d) wage terms, if not agreed in a collective agreement.

In addition to these mandatory requirements, which, if not all agreed, the employment contract does not arise, the law requires the employer to specify other working conditions in the employment contract. These are optional requirements, which include, according to Mucha (2020), payout dates, working hours, the period of leave and the length of notice. Otherwise, the employer shall inform the employee no later than one month after the conclusion of the employment contract. Applying the principle of dispositiveness allows the employment contract to agree on other conditions of interest, in particular other material advantages such as the 13rd salary, the employer's contribution at the birth of the child to the employee, etc.

In business practice, the misconception is that the probationary period is part of any employment relationship. As Mura (2019) emphasizes, the employee and the employer can only arrange a probationary period in the employment contract. This is the period during which either contracting party may terminate the employment relationship for any reason or without specifying it. A proba- tionary period can be agreed in a written contract, limited to a maximum of three months, and only for senior management positions it can be agreed at a maximum of six months. The Labor Code generally prohibits extending it. The exception is the obstacles to work on the employee's side. The agreement of a probationary period in an orally concluded employment contract is affected by a defect of absolute nullity, as well as its renegotiation in the event of fixed-term resumption.

With the advent of Industry 4.0, it attracts special attention to the institute of "management contract." Despite the fact that the Labor Code contains only its abrupt hints, it becomes a frequent legal basis for the mutual regulation of legal relations between entrepreneurs and their top managers. Management contract, according to Dudić et al. (2020), is concluded most often for the posts of directors of business, personnel and production departments, as well as a company and cooperatives. The relationship between an entrepreneur and a manager is an absolute business relationship according to the provisions of $\$ 261$ paragraph 3 of Act No 513/1991 Coll. Commercial Code, as amended (hereinafter referred to as 'the Commercial Code'). The Commercial Code as the lex generalis of Slovak commercial law rigorously determines the relationships that will be considered in the commercial law regime. One of these relationships is the relationship between a member of the statutory body and his company. Mura et al. (2020) point out that the Commercial Code generally requires the legal relationship between a company and a member of its body or a member of its body or partner to be applied in order to settle matters of the company, proportionately to the provisions of the mandate agreement. This rule shall be waived only if a contract for the performance of a function concluded between a company and a member of an organ of the company or a member of the body of the company or a partner does not result in any other determination of rights and obligations.

\subsection{Management contract}

A management contract does not exist as a separate contractual type. According to Monica et al. (2018), it should be understood alternatively. Either as an employment contract concluded un- 
der the Labor Code, or as a mandate agreement concluded under the Commercial Code. In practice, however, it is a non-nominate contract, which does not constitute the legal basis for the establishment and subsequent creation of an employment relationship. This view is based mainly on the universality of the Labor Code. This is the only contractual way to establish an employment contract. However, there is also an exception to this situation. In the law, the general rule is that a legal transaction, i.e. also a contract, is judged not by its name, but by its content. This means that a management contract can be the basis of an employment relationship if it contains mandatory terms of an employment contract. It is now common that the content of such a contract corresponds to all or at least mandatory terms of the employment contract and is drawn up in writing. Other arrangements of the Participants that do not conflict with the mandatory provisions of the Labor Code and other labor regulations may be beyond the content of the essential content requirements of the managerial contract (Jankowski, 2018). Participants in this employment relationship may adjust the specificities of a particular manager's functional position, the scope of his rights, obligations and obligations, as well as any consideration of the possible compensation. As Srebalová et al. (2020) state, there are other benefits related to the performance of managerial functions, such as a service mobile or a car. Such a bilateral legal transaction is then assessed on the basis of its content as an employment contract.

\subsection{Establishment and change of employment}

According to the Ministry of Labor, Social Affairs and Family of the Slovak Republic (2021), the employment relationship arises only from the date agreed in the employment contract as the day of entry into employment. From the date of its establishment, the employer is obliged to assign work to the employee according to the employment contract, pay wages for the work performed, create conditions for fulfilling the work tasks and respect other working conditions laid down by law, collective agreement and employment agreement. Labor Code obliges employees to carry out the work personally, according to the employer's instructions and according to the employment contract in specified working time, as well as to observe the discipline of work. Upon taking up employment, the employer informs him of the employment policy, the collective agreement, the legislation relating to the work performed by him, the legislation and other regulations to ensure safety and health at work that the employee must observe in his work, and also the provisions on the principle of equal treatment. In relation to a young employee, the employer's obligations are also extended to the employer's need to inform him and his legal representative of the potential risks of the work being carried out and the measures taken concerning health and safety at work.

Not only the Labor Code, but also Dan (2015) and Lalik (2020) state that case law prohibits an employer from assessing as a failure a situation where an employee refuses to perform work or follow instructions that are contrary to generally binding laws or good morals (e.g. washing the private car of a superior worker), or if they directly and seriously endanger the life or health of the employee or other persons. Other statutory obligations of the employer include reporting on the agreed new employment arrangements to employees' representatives that he has agreed with them.

\subsection{Agreement on changing working conditions}

The principle of dispositiveness expressed in the provision of $\$ 54$ of the Labor Code allows the parties to change the agreed content of an employment contract but only if the employer and the employee agree to change it. It then obliges the employer to make a change in the employment contract in writing. As with the employment contract, failure to comply with the written form does not invalidate the agreement on changing working conditions. In practice, it is most often a reassignment to another job, which can only be applied in exceptional cases. The reasons are unfavorable state of health, pregnancy of a woman, prevention of communicable diseases, final decision of a court or other body, or unfitness to work according to medical opinion or personal status.

Certain reasons, e.g. the lack of jobs at the employer, may lead to a situation where the goal of reassigning an employee within the framework of the 
employment contract cannot be achieved. Peráček et al. (2020) see the solution in the legal possibility of reassigning the employee but only in specific cases and in agreement with him for work of a different kind than agreed in the employment contract. At the same time, however, the employer must ensure that the work assigned to the employee corresponds to his/her fitness for work and is suitable for him in terms of his or her abilities and qualifications. The employer may only transfer the employee without his consent to the time necessary for work other than the agreed work if it is necessary to avert an emergency or mitigate its immediate consequences.

In addition to the situation to avert an extraordinary event or consequences from it, the Labor Code also regulates the procedural procedure for reassigning an employee. In particular, an employer is obliged to discuss with an employee in advance the reason for reassignment to another work and the period during which the reassignment is to last. As further Klimek and Funta (2021) state, if the reassignment of an employee results in a change of an employment contract, the employer is obliged to notify him in writing of the reason for reassignment to another work. However, the employer's failure to fulfill this obligation is not penalized by the legislature by a defect of absolute invalidity.

Before concluding an agreement to change working conditions prior to the transfer of the employee to work of a different kind than that agreed in the employment contract, the employer is obliged to arrange for his medical examination in cases provided for by special regulations. Payment for the healthcare provided pursuant to $\$ 56$ of the Labor Code may not be required of the employee, which implies that it is borne by his employer if it is not covered by the means of public health insurance.

An employer may send an employee on a work trip, which, according to the law, must be outside the district of the regular workplace or residence of the employee for a strictly necessary period, but only with his consent, unless the posting for a work trip results directly from the nature of the agreed type of work or place of employment or if the possibility of posting for a work trip is agreed in the work contract. On the journey, a staff member is obliged to perform work according to the instructions of his manager who posted him on his mission.

The temporary assignment of an employee to work with another employer is based solely on the agreement of both parties. As Peráček (2021) adds, without the consent of the employee, temporary assignment to another employer cannot be carried out. The employer or the temporary-work agency can therefore only agree in writing with the employee in employment on a temporary assignment to the user's employer under special legislation.

The provision of $\$ 58$ paragraph 6 of the Labor Code limits the length of temporary assignment of an employee to a maximum of 24 months, but with the possibility of further extension within 24 months not more than four times. This is also the case of a temporary assignment of an employee to another employer or another temporary-work agency to the same user employer. As Mura et al. (2019) warn, temporary assignment of an employee contrary to the provision of section 58 , paragraph 6, first and second sentences of the Labor Code is primarily sanctioned by termination of the employment relationship between an employee and an employer or temporary-work agency. The secondary consequence of breaking the law is the emergence of an indefinite employment relationship between the employee and the user employer. The user's employer shall be required to issue a written notice of its establishment to the employee no later than five working days from the date of such employment. Consequently, the provisions of the temporary assignment agreement or the employment contract according to the provisions of section 58 paragraph 5 of the Labor Code shall apply mutatis mutandis to the working conditions of the employee.

The User Employee grants the Labor Code the right to impose on an employee on behalf of the employer or agency during the temporary assignment of work tasks, to organize, manage and control his work, to give him instructions for this purpose. However, there are also obligations relating to the need to create favorable working conditions, to ensure safety and health at work, as well as to other employees. However, Jankurová et al. (2017) 
add that the manager of the user employer is deprived of the possibility of carrying out legal acts against the assigned employee on behalf of the employer or agency.

During a temporary assignment, the employer who has seconded the employee, or the Agency, usually pays the employee wages or travel compensation. This view is shared by Mura et al. (2021) and Prokopenko and Omelyaenko (2018), who add that they also ensure that working conditions, including wages, are as favorable as a comparable employee of the employer-user.

If the employer or the temporary-work agency has not provided the seconded employee with a salary at least as favorable as it belongs to a comparable employee of the user employer, he shall, within 15 days of the payout date agreed between the employer or the temporary-work agency and the seconded employee, grant him that salary or the difference. The obligation to provide the same salary or the difference of salary applies also to a user employer to whom an employee is posted to work by an employer or temporary-work agency from the territory of another Member State of the European Union to the territory of the Slovak Republic. It is right that the legislator, in particular, in order to eliminate possible disputes and ambiguities, lists various components of the same working conditions. These are:

a) working time, breaks at work, rest, overtime work, on-call time, night work, holidays;

b) wage conditions;

c) health and safety at work;

d) compensation for accidents at work or occupational diseases;

e) insolvency compensation and protection of claims of temporary staff;

f) protection of pregnant women, mothers until the end of the ninth month after childbirth, breastfeeding women, women and men caring for children and adolescents;

g) right to collective bargaining, food conditions (National Labor Inspectorate, 2021).
Any damage that the Labor Code resolves in such a way that whoever temporarily allocates and pays the employee damages arising from the performance of the work tasks or directly related to it with the user employer is entitled to compensation against the user employer provided that they have not agreed otherwise. The user employer has an obligation to inform the employer and the agency about the working and employment conditions of the comparable employee by himself.

Cajkova et al. (2021) also draw attention to the need for a user employer to keep a record of seconded employees containing the employee's identification details, identification data of the employer or temporary-work agency who temporarily assigned him the employee and the date of establishment and termination of the temporary assignment. It is also true that temporary employees are also counted for the purpose of selecting employees' representatives according to the provisions of $\$ 233$ paragraphs 2 and 3 of the Labor Code.

The employer or agency may also agree with the user employer about the temporary assignment of an employee in employment to perform work only if there are objective operational reasons for the employer. As Mucha (2019) emphasizes, in this case, it is necessary to draw up the agreement in writing, and it must contain the particulars referred to in $\$ 58$ a (2) of the Labor Code. Again, in this situation, the lack of a written form is affected by the defect of absolute nullity of a legal act, as the provision of $₫ 17$ paragraph 2 of the Labor Code means.

The provision of $\$ 58$ a paragraph 4 of the Labor Code requires the employer or the agency to provide the user employer immediately with the data necessary to check their compliance with the obligation in relation to the wage conditions of employees temporarily assigned to it. Such a check gives the user employer the possibility to pay an equally favorable wage.

\section{DISCUSSION}

Within the framework of the discussion, one can agree with the opinions of several authors, espe- 
cially in the case of practitioners. In practice, there were situations where seconded employees were certified, and it was in the interest of both the user employer and the employee to conclude a contract of employment without the participation of a third party, i.e. temporary-work agencies. Such a procedure was prevented by contractual terms prohibiting their circumvention and employment. The legislator's response was the amendment of the Labor Code, which declared the agreements prohibiting the conclusion of employment between the user employer and the employee after being assigned by the temporary-work agency or employers to be invalid.
Termination of a temporary assignment can occur on the basis of several options. The first one is, according to Kováčik and Imrovič (2019), the end of the temporary secondment after the agreed time is elapsed. Before its expiry, it is possible to end it by agreement of the parties or unilateral termination of the parties on the basis of already agreed conditions, or by decision of a court or other body, e.g. the department of aliens police. The legislator did not consider it necessary to specifically adjust the formalities of unilateral termination of the employment relationship and therefore it is necessary to apply the provisions of the Labor Code on termination.

\section{CONCLUSION}

In view of the stated objective of this paper, a conclusion was made by analyzing scientific and academic literature, legislation and jurisprudence using the institute of legal logic that the Labor Code, as a lex generalis of labor law of the Slovak Republic, contains a seemingly thorough comprehensive legal regulation of labor law. It fulfills its purpose and provides an employee, as the weaker party in employment relations, with the necessary protection. At the same time, within the framework of the principle of dispositiveness and contractual freedom, on which it is built, the agreement allows the employee to grant more rights than guaranteed by the Labor Code. However, the added value of the investigation is a series of findings. It is necessary to critically assess the lack of interest of the legislator in securing in the Labor Code the possibility of implementing certain legal acts in electronic form. In the era of electronicization of public administration, the law could enable the employees to agree on a number of electronic forms. The expansion of ID cards with a chip and associated employee advanced electronic signature with a time stamp only supports this proposal "de lege ferenda".

It was also found that a management contract does not exist as a subtype of an employment contract. It would be appropriate for the legislator to deal with this problem and to modify it at least as a subtype of an employment contract. This would eliminate possible uncertainties and disputes in the future, thus avoiding potential litigation with uncertain results. In conclusion, it must be said that the greatest challenge for the management of companies in managing human resources is the state of a certain 'legal unconsciousness'. However, it is a problem that can be solved relatively easily through a thorough study of the legislation and available relevant labor law literature, which can also be of great help to secondary schools and universities themselves.

\section{AUTHOR CONTRIBUTIONS}

Conceptualization: Tomáš Peráček.

Data curation: Tomáš Peráček.

Formal analysis: Tomáš Peráček.

Funding acquisition: Tomáš Peráček.

Investigation: Tomáš Peráček.

Methodology: Tomáš Peráček.

Project administration: Tomáš Peráček.

Resources: Tomáš Peráček.

Software: Tomáš Peráček. 
Supervision: Tomáš Peráček.

Validation: Tomáš Peráček.

Visualization: Tomáš Peráček.

Writing - original draft: Tomáš Peráček.

Writing - review \& editing: Tomáš Peráček.

\section{ACKNOWLEDGMENT}

This scientific paper was created within the project VEGA [1/0320/21] "The Role of Universities in Building the Knowledge Economy" and was supported by funds from Comenius University in Bratislava, Faculty of Management.

\section{REFERENCES}

1. Barteková, M., \& Šlahor, L. (2018). Analysis of financial conditions of students' life in Slovakia: The case of student loans. Proceedings of the 32nd International Business Information Management Association Conference, IBIMA 2018 - Vision 2020: Sustainable Economic Development and Application of Innovation Management from Regional expansion to Global Growth, 2897 2909.

2. Cajková, A., Jankelová, N., \& Masár, D. (2021). Knowledge management as a tool for increasing the efficiency of municipality management in Slovakia. Knowledge Management Research and Practice. https://doi.org/10.1080/1 4778238.2021.1895686

3. Dan, H. (2015). Cultural differences as obstacles in the European economic integration process - a labour market perspective. Online Journal Modelling the New Europe, 15(1), 76-96.

4. Dudić, B., Dudić, Z., Pejanović, R., Škatarič, G., Saxunová, D., \& Peráček, T. (2020). The rural policy of Slovakia after joining the EU. Agriculture and Forestry, 66(3), 33-51. https://doi.org/10.17707/ AgricultForest.66.3.04

5. Federal Assembly of CSFR. (1991). Act No. 513/1991 Coll. Commercial Code, as amended [online]. [cit. 2021-06-29]. Retrieved from https://www. slov-lex.sk/pravne-predpisy/SK/ ZZ/1991/513/20201001
6. Ispas, G. L. (2021). Impact of the COVID-19 on the migration in the European Union. Juridical Tribune, 11(1), 30-41.

7. Jankowski, B. (2018). Changes in the European development policy after 2020. Conclusions for the Visegrád Group. Online Journal Modelling the New Europe, 26, 52-77. https://doi.org/10.24193/ OJMNE.2018.26.05

8. Jankurová, A., Ljudvigová, I., \& Gubová, K. (2017). Research of the nature of leadership activities. Economics and Sociology, 10(1), 135-151. https://doi.org/10.14254/2071789X.2017/10-1/10

9. Klimek, L. \& Funta, R. (2021). Data and E-commerce: An Economic Relationship. Danube, 12(1), 33-44. https://doi. org/10.2478/danb-2021-0003

10. Kováčik, V., \& Imrovič, M. (2019). Implementation of the EU operational program employment and social inclusion in the Slovak republic in the context of selected social indicators. Online Journal Modelling the New Europe, 30, 23-42. https://doi.org/10.24193/ OJMNE.2019.30.02

11. Lalík, T. (2020). The Slovak constitutional court on unconstitutional constitutional amendment (pl. ÚS 21/2014) European Constitutional Law Review, 16(2), 328-343. https://doi. org/10.1017/S1574019620000140

12. Ministry of Labor, Social Affairs and Family of the Slovak Repub- lic. (2021). Work and Employment. [online]. [cit. 2021-06-29]. Retrieved from https://www. employment.gov.sk/sk/pracazamestnanost/

13. Monica, B.-V., Dan, H., \& Maniu, M. (2018). Policy design for competitiveness. A heterodox view on the present day governance of the Romanian economic life and business environment. Online Journal Modelling the New Europe, 25, 4-26. https://doi.org/10.24193/ OJMNE.2018.25.01

14. Mucha, B. (2019). Tools to increase the effectiveness of comprehensive management of emergencies affected by climate change in the Slovak republic. 19th International Multidisciplinary Scientific Geoconference, SGEM, 573-580.

15. Mucha, B. (2021). Evaluation of the State of Implementation of the European Structural and Investment Funds: Case Study of the Slovak Republic. Online Journal Modelling the New Europe, 35, 4-24. https://doi.org/10.24193/ OJMNE.2021.35.0

16. Mura, L., Gontkovicova, B., Dulova Spisakova, E. \& Hajduova, Z. (2019). Position of Employee Benefits in remuneration Structure. Transformations in Business \& Economics, 18(2), 156173.

17. Mura, L., Zsigmond, T., Kovacs, A., \& Baloghová, É. (2020). Unemployment and GDP relationship in the Visegrad Four countries. 
Online Journal Modelling the New Europe, 34, 118-134. https://doi. org/10.24193/OJMNE.2020.34.06

18. National Council of the Slovak Republic. (2001). Act No. 311/2001 Coll. on the Labour Code, as amended [online]. [cit. 2021-0629]. Retrieved from https://www. slov-lex.sk/pravne-predpisy/SK/ ZZ/2001/311/20200730

19. National Council of the Slovak Republic. (2004). Act No. 365/2004 Coll. on Equal Treatment in Certain Areas and on Protection from Discrimination and on Amendments to Certain Acts (Anti-Discrimination Act), as amended [online]. [cit. 2021-0629]. Retrieved from https://www. slov-lex.sk/pravne-predpisy/SK/ ZZ/2004/365/20160102

20. National Council of the Slovak Republic. (2005). Act No. 82/2005 Coll. on Undeclared Work and Undeclared Employment and on Amendments to Certain Acts, as amended. [online] [cit. 2021-0629]. Retrieved from https://www.
slov-lex.sk/pravne-predpisy/SK/ ZZ/2005/82/20200101

21. National Labor Inspectorate. (2021). Labor relations. [online] [cit. 2021-06-29]. Retrieved from https://www.ip.gov.sk/pracovnopravne-vztahy/

22. Peráček, T. (2021). The perspectives of European society and the European cooperative as a form of entrepreneurship in the context of the impact of European economic policy. Online Journal Modelling the New Europe, 34 38-56. https://doi.org/10.24193/ OJMNE.2020.34.02

23. Peráček, T., Vilčeková, L. \& Strážovská, L. (2020). Selected problems of family business: A case study from Slovakia. Acta Polytechnica Hungarica, 17(7), 145-162. https://doi.org/10.12700/ APH.17.7.2020.7.8

24. Plavčan, P., \& Funta, R. (2020). Some Economic Characteristics of Internet Platforms. Danube, 11(2), 156-167. https://doi.org/10.2478/ danb-2020-0009
25. Prokopenko, O., \& Omelyanenko, V. (2018). Marketing aspect of the innovation communications development. Innovative Marketing, 14(2), 41-49. https://doi. org/10.21511/im.14(2).2018.05

26. Srebalova, M., Horvath, M., Vacok J., Vojtech F., \& Filip, S. (2020). Legal obstacles to freedom to conduct a business: experience of the Slovak Republic. Entrepreneurship and Sustainability Issues, 7(4), 3385-3394. https://doi. org/10.9770/jesi.2020.7.4(53)

27. Srebalová, M. \& Vojtech, F. (2021). SME Development in the Visegrad Area. Eurasian Studies in Business and Economics, 17, 269281. https://doi.org/10.1007/9783-030-65147-3_19

28. Vaníčková, R. \& Bílek, S. (2021). Employee privacy protection versus interests and property employer. International Journal of Law and Management. https://doi. org/10.1108/IJLMA-06-2016-0055 